\title{
BERAT POTONG, BERAT KARKAS DAN PERSENTASE KARKAS TERNAK SAPI BALI DI RUMAH POTONG HEWAN (RPH) KABUPATEN SORONG
}

\author{
Charliany Hetharia ${ }^{1}$ \\ Universitas Victory Sorong \\ Janethnadin270416@gmail.com \\ Siprianus Sanda ${ }^{2}$ \\ seprianusanda@gmail.com
}

\begin{abstract}
Abstrak
Penelitian ini bertujuan untuk mengetahui berat potong, berat karkas dan persentase karkas ternak sapi Bali di RPH Kabupaten Sorong. Materi yang digunakan pada penelitian ini adalah 20 ekor ternak sapi bali jantan yang berumur diatas 2 tahun. Peralatan yang digunakan pada penelitian ini adalah timbangan digital dan meteran. Penelitian dilaksanakan pada bulan Juni sampai dengan bulan Agustus 2020 di RPH Kabupaten Sorong, Jl. Flamboyan, Distrik Mariat-Kabupaten Sorong. Peubah yang diamati dalam penelitian ini adalah berat potong, berat karkas dan presentase karkas. Metode yang digunakan pada penelitian ini adalah metode observasi, wawancaran dan pengukuran serta penimbangan untuk menetahui peubah yang diamati. Hasil penelitian menunjukkan bahwa nilai rataan berat potong $325,96 \mathrm{~kg}$, berat karkas $175,25 \mathrm{~kg}$ dan persentase karkas 55,66 \%. Berdasarkan hasil penelitian tersebut diatas, disimpulkan bahwa ternak sapi Bali yang dipotong di RPH Kabupaten Sorong masih sangat rendah sehingga perlu ditingkatkan dalam aspek berat potong dan berat karkas.
\end{abstract}

Kata kunci: Sapi Bali, Berat potong, berat karkas,

\begin{abstract}
Abstrac
This study aims to determine the slaughter weight, carcass weight and carcass percentage of Bali cattle in the abattoir of Sorong Regency. The material used in this study were 20 male Bali cattle over 2 years old. The equipment used in this research are digital scales and meters. The research was carried out from June to August 2020 at the Sorong Regency RPH, Jl. Flamboyan, Mariat District, Sorong Regency. The variables observed in this study were slaughter weight, carcass weight and carcass percentage. The method used in this study is the method of observation, interview and measurement and weighing to determine the observed variables. The results showed that the average value of slaughter weight was $325.96 \mathrm{~kg}$, carcass weight was $175.25 \mathrm{~kg}$ and carcass percentage was $55.66 \%$. Based on the results of the research above, it was concluded that Bali cattle slaughtered at the RPH Sorong Regency is still very low so it needs to be increased in terms of slaughter weight and carcass weight.
\end{abstract}

Keywords: Bali cattle, slaughter weight, carcass weight 


\section{PENDAHULUAN}

Peningkatan pertumbuhan ekonomi dewasa ini terjadi seiring dengan meningkatnya jumlah penduduk sehingga menyebabkan perubahan pola konsumsi dan selera masyarakat, yang mengakibatkan terjadinya peningkatan konsumsi daging sapi secara nasional (Firdaus et al., 2012). Meningkatnya jumlah penduduk, membuat kebutuhan manusia meningkat pula. Hal ini memacu manusia untuk mencari dan menyiapkan sumber pangan yang berkualitas. Salah satu sumber pangan yang berkualitas adalah sumber protein hewani (daging, telur dan susu). Di Indonesia ternak sapi potong (pedaging) merupakan sumber pangan penghasil daging yang sangat dibutuhkan. Produktivitas sapi potong masih rendah sehingga menyebabkan belum terpenuhinya kebutuhan daging oleh konsumen.

Sapi Bali di Kabupaten Sorong lebih diandalkan sebagai salah satu ternak ruminansia besar yang menghasilkn daging untuk memenuhi kebutuhan konsumen di kota Aimas maupun kota Sorong dan sekitarnya. Di Kabupaten Sorong Sapi Bali mempunyai keunggulan diantaranya memiliki daya adaptasi yang tinggi, memanfaatkan pakan yang berkualitas rendah serta mempunyai kesuburan yang tinggi. Produktivitas ternak sangat dipengaruhi oleh berbagai faktor yaitu faktor genetik dan faktor lingkungan. Faktor genetik yang mempengaruhi penampilan ternak berkaitan dengan gen-gen yang yang dimiliki oleh seekor ternak sedangkan faktor lingkungan merupakan faktor pendukung bagi kelangsungan hidup ternak serta produksinya.

Kabupaten Sorong yang merupakan sentra produksi sapi memiliki potensi besar untuk pengembangan ternak sapi karena didukung oleh sumber daya alam untuk lahan dan pakan, sumber daya manusia serta peluang pasar. Salah satu ternak sapi lokal yang ada di Kabupaten Sorong adalah sapi Bali. Menurut Ngadiyono et al (2008) sapi yang dapat hidup di wilayah tropis memiliki kemampuan beradaptasi serta dapat merespon dengan baik pemberian pakan berkualitas untuk menghasilkan karkas yang baik pula.

Rumah Potong Hewan (RPH) menurut Surat Keputusan Menteri Pertanian No. 555/ Kpts/ TN. 240/ 1986 adalah bangunan atau komplek bangunan dengan desain tertentu yang digunakan sebagai tempat memotong hewan selain unggas bagi konsumsi masyarakat. Indikator produksi daging dari seekor ternak pedaging bisa diukur dari berat dan persentase karkas yang dihasilkan sebab pada karkas terkandung otot yang selanjutnya akan terkonversi menjadi daging. Rumah Potong Hewan (RPH) Kabupaten Sorong sebagai penghasil utama daging sapi di Kabupaten Sorong hingga saat ini belum memiliki data produksi karkas yang memadai.

Berdasarkan uraian tersebut diatas, maka penelitian ini bertujuan untuk mengetahui berat potong, berat karkas dan presentase karkas ternak sapi bali di RPH Kabupaten Sorong sehingga bermanfaat untuk perencanaan dalam upaya pemenuhan permintaan daging dan pengembangan peternakan sapi bali di Kabupaten Sorong. 


\section{KAJIAN TEORI}

Penelitian yang dilaksanakan oleh Marino et al (2020) ini bertujuan untuk mengetahui berat potong, berat karkas dan persentase karkas ternak sapi potong lokal Sulawesi Utara yang dipotong di RPH Manado. Materi yang digunakan dalam penelitian ini adalah 40 ekor ternak sapi potong lokal Sulawesi Utara yang ada di RPH, Manado. Peralatan yang digunakan dalam penelitian ini ialah meteran dan timbangan gantung. Penelitian ini menggunakan metode observasi, wawancara langsung serta pengukuran yang dilakukan secara acak dan penimbangan untuk mengetahui berat potong, berat karkas dan persentase karkas. Hasil penelitian menunjukan bahwa nilai rataan berat potong $271,475 \mathrm{~kg} \pm 34,129$, berat karkas $136,025 \mathrm{~kg} \pm 16,477$ dan persentase karkas 50,168\% $\%$ 1,694. Berdasarkan hasil penelitian disimpukan bahwa ternak sapi potong lokal yang di potong di RPH Manado masih tergolong rendah dilihat dari aspek berat potong dan berat karkas.

Penelitian yang dilaksanakan oleh Yosita et al (2012) bertujuan untuk mengetahui persentase karkas, tebal lemak punggung dan indeks perdagingan sapi Bali, sapi Peranakan Ongole (PO) dan sapi Australian Commercial Cross (ACC). Penelitian dilakukan pada tanggal 1 sampai 30 Desember 2011 di Rumah Potong Hewan Kota Tasikmalaya dengan menggunakan masing-masing 15 ekor sapi Bali, sapi PO dan sapi ACC dengan kisaran umur 2,5-3,5 tahun. Metode penelitian yang digunakan adalah studi kasus melalui pengamatan langsung di Rumah Potong Hewan.Peubah yang diukur adalah bobot potong, bobot karkas, persentase karkas, tebal lemak punggung, panjang karkas dan indeks perdagingan. Hasil Penelitian menunjukkan bahwa persentase karkas sapi Bali sebesar 53,26 \%, sapi PO 46,9 \%dan sapi ACC 51,27\%. Nilai tebal lemak punggung sapi ACC sebesar 9,53 mm diikuti sapi Bali dan PO masing-masing 8,40 $\mathrm{mm}$ dan 6,03 mm.Sedangkan nilai indeks perdagingan sapi ACC bernilai 1,61, sapi Bali 1,47 dan sapi PO 1,31.

Penelitian yang dilaksanakan oleh Ngadiyono et al (2008) bertujuan untuk mengetahui pengaruh lama pemuasaan dan berat hidup terhadap persentase karkas dan persentase bagianbagian karkas sapi lokal. Penelitian ini menggunakan ternak sapi lokal yang dipotong (disembelih) di Rumah Potong Hewan (RPH) PT. Abattoir Surya Jaya Surabaya. Sebanyak 24 ekor sapi lokal dikelompokkan menjadi 2 kelompok berat hidup yaitu 200-250 dan 251- 300 kg. Masing-masing kelompok berat hidup dibagi menjadi 4 macam lama pemuasaan yaitu 0 , 4, 8 dan 12 jam. Sapi kemudian dipotong dan diproses menjadi karkas. Variabel yang diamati adalah persentase karkas dan bagian karkas yang terdiri dari blade, shank, topside, inside, silverside, cuberoll, sirloin, fillet, rump, flank, brisket, rib meat dan chuck. Data dianalisis menggunakan rancangan acak lengkap pola faktorial $2 \times 4$. Hasil penelitian menunjukkan bahwa lama pemuasaan tidak mempengaruhi persentase karkas dan bagian-bagian karkas. Persentase karkas sapi lokal dengan lama pemuasaan 0, 4, 8 dan 12 jam masing-masing adalah 48,63; 48,98; 47,21 dan 49,16\%. Berat hidup3-4= 251-300 kg mempunyai persentase karkas lebih tinggi (51,26\%) dibandingkan dengan berat hidup 200-250 kg (45,73\%). Kesimpulan yang dapat diambil berdasarkan penelitian adalah perlakuan lama pemuasaan sampai dengan 12 jam tidak menyebabkan penurunan bobot hidup sapi lokal. 


\section{METODE PENELITIAN}

Penelitian ini dilaksanakan selama 2 bulan (Juni - Agustus 2020) Rumah Potong Hewan (RPH) Kabupaten Sorong Jalan Flamboyan, Distrik Mariat-Kabupaten Sorong. Materi ang digunakan pada penelitian ini adalah adalah 20 ekor ternak sapi bali jantan yang berumur diatas 2 tahun. Peralatan yang digunakan pada penelitian ini adalah timbangan digital dan meteran.

Metode yang digunakan pada penelitian ini adalah metode observasi, wawancaran dan pengukuran serta penimbangan untuk menetahui peubah yang diamati. Peubah yang diamati dalam penelitian ini adalah berat potong, berat karkas dan presentase karkas

\section{Berat Potong}

Berat potong diperoleh dengan cara mengukur panjang badan dan lingkar dada sapi, kemudian dihitung dengan menggunakan rumus Winter Indonesia (Santosa, 2008) sebagai berikut :

$$
\begin{aligned}
\text { Berat Potong }(\mathbf{k g})=\frac{\mathrm{LD}^{2} \times \mathrm{PB}}{10815,15} \\
\text { dimana, } \quad \mathrm{LD}=\text { Lingkar Dada }(\mathrm{cm}) \\
\mathrm{PB}=\text { Panjang Badan }(\mathrm{cm})
\end{aligned}
$$

\section{Berat Karkas}

Berat karkas didapat dengan cara menimbang seluruh daging dan tulang setelah dikurangi darah, kepala, kulit, organ bagian dalam dan keempat kaki menggunakan timbangan gantung digital.

\section{Persentase Karkas}

Persentase karkas diperoleh dengan membandingkan berat karkas dengan berat potong kemudian dikalikan $100 \%$. Rumus sederhananya dapat dilihat dibawah ini :

$$
\text { Persentase Karkas }=\frac{\text { Berat Karkas }}{\text { Berat Potong }} \times 100
$$

Data dianalisa secara deskriptif dengan menghitung rataan berat potong, berat karkas, dan persentase karkas ternak sapi bali di Rumah Potong Hewan Kabupaten Sorong.

\section{HASIL DAN PEMBAHASAN}

\section{Berat Potong}

Berdasarkan data penelitian pada Tabel 1, dapat dilihat bahwa nilai rataan berat potong ternak sapi Bali di RPH Kabupaten Sorong adalah 325, $96 \mathrm{~kg}$. Hasil penelitian yang diperoleh ini lebih kecil jika dibandingkan dengan hasil penelitian Yosita et al (2012) yang memperoleh rataan berat potong 343, $40 \mathrm{~kg}$ dan lebih besar dari hasil penelitian Marino et al (2020) yang memperoleh berat potong sebesar 271, $475 \mathrm{~kg}$. Hal yang sama juga diperoleh dari beberapa hasil penelitian lainnya, seperti dalam Carvalho et al (2010) yang memperoleh berat potong sebesar $395,76 \mathrm{~kg}$. Begitu pula dengan hasil yang diperoleh oleh Hafid et al (2013) yang memperoleh rataan berat potong 448,36 kg. Berat potong sapi dari hasil 
penelitian di RPH Kabupaten Sorong sangat rendah, hal ini diduga disebabkan oleh faktorfaktor diantaranya genetika ternak, jenis kelamin dan umur ternak.

Berat potong ternak sapi dapat meningkat apabila faktor-faktor sebelum pemotongan ternak sapi diperhatikan dengan baik. Hal ini sejalan dengan Hidayat et al. (2015) yang menyatakan bahwa faktor-faktor sebelum pemotongan dapat mempengaruhi berat potong antara lain genetik, spesies, bangsa, tipe ternak, jenis kelamin, umur, pakan termasuk bahan aditif (hormon, antibiotik dan mineral) dan stres. Faktor-faktor tersebut berpengaruh terhadap pertumbuhan dan perkembangan sapi potong yang dapat meningkatkan berat potong seiring dengan pertumbuhan dan perkembangan bagian-bagian tubuh atau karkas.

Tabel 1.Nilai Rataan Berat Potong, Berat Karkas dan Persentase Karkas Ternak Sapi Bali yang Dipotong di RPH Kabupaten Sorong

\begin{tabular}{ccc}
\hline No. & Variabel & Nilai Rataan (mean) \\
\hline 1 & Berat Potong & $\mathbf{3 2 5 , 9 6} \mathbf{~ k g}$ \\
2 & Berat Karkas & $\mathbf{1 7 5 , 2 5} \mathbf{~ k g}$ \\
3 & Persentase Karkas & $\mathbf{5 5 , 6 6 \%}$ \\
\hline
\end{tabular}

Sumber : Data Penelitian (diolah)

\section{Berat Karkas}

Berdasarkan data hasil penelitian pada Tabel 1, terlihat bahwa nilai rataan berat karkas ternak sapi Bali di RPH Kabupaten Sorong adalah 175,25 kg. Dari data tersebut terlihat bahwa berat karkas sapi Bali tergolong kecil mengikuti berat potong yang dihasilkan. Kecilnya nilai berat karkas ternak sapi Bali di RPH Kabupaten Sorong disebabkan karena komponen utama karkas seperti proporsi tulang, otot, dan lemak dipengaruhi oleh berat hidup, dan laju pertumbuhan. Laju pertumbuhan, nutrisi, umur dan berat tubuh adalah faktor-faktor yang saling berhubungan satu dengan lainnya, yang dapat secara individu atau kombinasi mempengaruhi karkas. Menurut Soeparno (2005) umur seleksi untuk berat potong yang tinggi dapat mempengaruhi komposisi tubuh dan karkas. Sedangkan menurut Wiyatna (2007), berat karkas ternak sapi bervariasi dipengaruhi oleh bobot hidup, bangsa, jenis kelamin, makanan dan kondisi tubuh ternak.

Berat karkas merupakan salah satu faktor yang diperhatikan dalam penilaian karkas. Berat karkas berhubungan erat dengan berat potong, dimana semakin tinggi berat potong, maka semakin tinggi pula berat karkas. Hal ini sejalan dengan Forrest et al. (1975) yang mengemukakan bahwa berat karkas semakin tinggi seiring dengan meningkatnya bobot potong. Demikian juga dengan jenis kelamin ternak yang berpengaruh terhadap berat karkas dimana berat karkas ternak jantan lebih tinggi dari betina. Hal ini disebabkan karena ternak jantan memiliki berat potong yang lebih tinggi dari ternak betina, dimana pertumbuhan ternak jantan lebih tinggi dibanding ternak betina, karena ternak jantan memiliki hormon steroid yang berperan dalam pertumbuhan dan perkembangan ternak jantan. Hal ini sejalan dengan Soeparno (2005) yang mengemukakan bahwa laju pertumbuhan jenis kelamin jantan lebih besar dibanding dengan betina, dan didukung oleh hasil penelitian Rosnah (2002) pada sapi Bali di dataran rendah dan dataran tinggi dengan kelompok berat potong 243 dan $210 \mathrm{~kg}$ 
berpengaruh terhadap berat karkas yang dihasilkan, dimana berat potong yang tinggi maka berat karkas yang dihasilkanpun tinggi. Selanjutnya dikatakan bahwa ternak sapi Bali yang mempunyai berat karkas yang tinggi mempunyai pertambahan berat badan harian yang tinggi pula.

\section{Persentase Karkas}

Berdasarkan Tabel 1, terlihat bahwa nilai rataan persentase karkas ternak sapi Bali di RPH Kabupaten Sorong sebesar 55,66 \%. Nilai ini dapat meningkat jika memperhatikan faktor-faktor yang mempengaruhi persentase karkas itu sendiri. Menurut Soeparno (2005), ada beberapa faktor yang mempengaruhi persentase karkas, yang utama yaitu konformasi tubuh dan derajat kegemukan. Ternak yang gemuk, persentase karkasnya tinggi dan umumnya berbentuk tebal seperti balok. Sedangkan ternak yang langsing, badan panjang, leher panjang dan berbentuk segitiga seperti sapi perah, persentase karkasnya umumnya rendah. Faktor lain yang juga berpengaruh terhadap persentase karkas adalah jumlah pakan yang ada dan air pada saluran pencernaan ternak. Bila jumlahnya cukup banyak maka persentase karkasnya akan rendah. Kulit yang besar dan juga tebal akan berpengaruh terhadap persentase karkas. Ngadiono (1995) mengemukakan bahwa perbedaan rataan persentase karkas disebabkan oleh perbedaan ukuran saluran pencernaan dan organ-organ penting non-karkas serta kondisi ternak. Selanjutnya dikatakan bahwa kondisi penimbangan ternak dan karkas, metode pengulitan, ukuran saluran pencernaan dan organ-organ penting serta kodisi finish (akhir) dari ternak juga berpengaruh terhadap persentase karkas. Hasil penelitian Rosnah (2002) pada sapi Bali di daerah dataran rendah dan tinggi diperoleh persentase karkas 47.75 dan $53.11 \%$.

Aktivitas bekerja dari sapi jantan akan berdampak terhadap pertumbuhan otot-otot (daging) tertentu serta dapat mempengaruhi ukuran serat daging (myofilamen) dibandingkan dengan ternak yang kurang beraktivitas. Hal ini sesuai dengan pendapat Soeparno (2005) yang bahwa aktivitas fisik seperti berolahraga akan mempengaruhi pertumbuhan otot, persentase terhadap karkas serta kualitas karkas dan daging yang dihasilkan olehh ternak tersebut. Hafid (2005) menambahkan bahwa ternak yang banyak bergerak atau beraktivitas akan menghasilkan daging yang lebih leaner (daging yang lemaknya lebih sedikit) sebab cadangan energi dalam lemak dalam otot akan digunakan selama aktivitas fisik tersebut. Daging merupakan hasil utama dari sapi pedaging, maka data produksi daging sangat diperlukan dan bermanfaat untuk merencanakan upaya pemenuhan permintaan daging dan pengembangan peternakan sapi dimasa yang akan dating. Hal ini sesuai dengan pendapat Hafid (2011) yang menyatakan bahwa indikator produksi daging dari seekor sapi pedaging dapat diukur dari berat dan presentase karkas yang dihasilkan, sebab pada karkas terkandung otot yang selanjutnya akan terkonversi menjadi daging. Karkas adalah hasil pemotongan ternak setelah dikeluarkan bagian non karkas atau offal. Kualitas dan kuantitas karkas sangat tergantung pada kondisi pemeliharaan, umur, bangsa, jenis kelamin dan makanan. Hal ini sesuai dengan Berg dan Butterfield (1976) dan hasil penelitan Hafid (2005) yang menyatakan bahwa perbedaan steroid kelamin diantara ternak jantan dan betina mempengaruhi komposisi karkas ternak 


\section{KESIMPULAN}

Berdasarkan hasil penelitian dapat disimpukan bahwa ternak sapi bali yang di potong di RPH Kabupaten Sorong masih tergolong rendah dilihat dari aspek berat potong dan berat karkas.

\section{DAFTAR PUSTAKA}

Berg RT, Butterfield RM. 1976. New concepts of cattle growth. Sydney University Press, Sydney

Carvalho, M. C., Soeparno dan N. Ngadiyono. 2010. Pertumbuhan dan produksi karkas Sapi Peranakan Ongole dan Simmental Peranakan Ongole jantan yang dipelihara secara .feedlot. Buletin Peternakan. 34(1) : 38-46.

Firdaus, A., T. Susilawati, M. Nasich dan Kuswati. 2012. Pertambahan bobot badan harian Sapi Brahman Cross pada bobot badan dan Frame Zize yang berbeda. J. Ternak Tropika 13(1): 48-62.

Forrest JC, Elton DA, David EG, Edward WM. 1975. Principles of Meat Science. United States of America

Hafid H. 2005. Kajian pertumbuhan dan distribusi daging serta estimasi produktivitas karkas sapi hasil penggemukan. Disertasi. Program Pasca Sarjana. IPB. Bogor.

Hafid H. 2011. Pengantar evaluasi karkas. Cetakan Pertama. Penerbit Unhalu Press, Kendari

Hafid, H., Nuraini dan Herman. 2013. Karakteristik karkas dan bagianbagian karkas Sapi Peranakan Ongole jantan dan betina pada peternakan rakyat di Provinsi Sulawesi Tenggara. Prosiding. Seminar Nasional Teknologi Peternakan dan Veteriner.

Hidayat, M. A., Kuswati dan T. Susilawati. 2015. Pengaruh lama istirahat terhadap karakteristik karkas dan kualitas fisik daging Sapi Brahman Cross Steer. Universitas Brawijaya, Malang. Jurnal Ilmu-ilmu Peternakan. 25(2) : 71-79. Malewa, A. 2009. Penaksiran bobot badan berdasarkan lingkar dada dan panjang badan Domba Donggala. J. Agroland 16 (1): 91-97.

Marino, Fernando Andris., A. Lomboan., E. Pudjihastuti., E.H.B. Sondakh. 2020. Berat Potong, Berat Karkas Dan Persentase Karkas Ternak Sapi Potong Lokal Yang Dipotong Di Rumah Potong Hewan Manado. Zootec Vol. 40 No. 1 : 191 - 195

Nusi, M., R. Utomo dan Soeparno. 2011. Pengaruh penggunaan tongkol jagung dalam Complete Feed dan suplementasi Undegrade Protein terhadap pertambahan bobot badan dan kualitas daging pada Sapi Peranakan Ongole. Buletin Peternakan 35(3): 173 181.

Ngadiyono N. 1995. Pertumbuhan dan sifat-sifat karkas dan daging sapi sumba ongole, Brahman cross dan Australian comersial cross yang dipelihara secara intensif pada berbagai bobot potong. [disertasi] program pasca sarjana IPB.

Ngadiyono, N., G. Murdjito, A. Agus dan U. Supriyana. 2008. Kinerja produksi Sapi Peranakan Ongole jantan dengan pemberian dua jenis konsentrat yang berbeda. J. Indon. Trop. Anim. Agric. 33(4): 282-289.

Rosnah US. 2002. Produksi Karkas sapi Bali Yang Digembalakan Pada Ketinggian Tempat Berbeda Di Timor. Buletin Nutrisi, Jurusan Nutrisis dan Makanan Ternak, Fakultas Peternakan Universitas Nusa CendanaKupang. ISSN: 1410-6191. Juli 2002. Vol 5 No 3.

Santosa, U. 2008. Manajemen Usaha Ternak Potong. Jakarta: Penebar Swadaya 
Soeparno. 2005. Ilmu dan Teknologi Daging. Cetakan ke-4. Gadjah Mada University. Yogyakarta

Surat Keputusan Menteri Pertanian No. 555/ Kpts/ TN. 240/ 1986 tentang Syarat-Syarat Rumah Potong hewan dan usaha Pemotongan hewan

Wiyatna, M. F. 2007. Perbandingan indek sapi-sapi indonesia (sapi bali, madura, po) dengan Sapi Australia Commercial Cross (ACC). Jurnal Ilmu Ternak 1 (7): 22-25

Yosita, M., S. Undang, dan E.Y. Setyowati. 2012. Persentase karkas, tebal lemak punggung dan indeks perdagingan Sapi Bali, Peranakan Ongole dan Aurtralian Commersial Cross. Diakses pada http://jurnal.unpad.ac.id/ejournal/art icle/view/887/993. 23 Januari 2020. 